\title{
The country-of-origin effect and the international expansion of Spanish fashion companies, 1975-2015 ${ }^{12}$
}

José Antonio Miranda

University of Alicante

\begin{abstract}
This paper deals with the influence of the country brand in the fashion industries. It explains how some Spanish fashion companies have achieved a prominent position in the international market without the support of a positive "country of origin effect", and why their success has not generated a reinforcement of the image of Spain in the fashion market. The paper examines the evolution of the image of Spain and the Spanish fashion abroad, and the internationalization of the main Spanish fashion companies, highlighting the keys of the limited influence of the country brand in the success of these companies.
\end{abstract}

Keywords: Country of origin; Spanish fashion; fashion retailing; international markets; corporate strategy; Inditex; Mango.

Over the course of approximately 20 years, between 1990 and 2010, several Spanish fashion companies have transformed from being practically unknown outside of Spain to being present in the main shopping streets all around the world. Brands such as Zara, Mango, Bershka or Desigual currently have thousands of stores in about a hundred countries and the vast majority of the products of these brands are sold outside Spain. The leading Spanish fashion group, Inditex, is the largest clothing retailer in the world. They have achieved this without the support of an influential country brand to provide positive connotations in the fashion world, despite having to compete in the international market with companies that are supported by a very powerful country of origin effect.

On the other hand, the international expansion of these Spanish fashion companies has not provided a significant improvement in the value of the "made in Spain" brand for

\footnotetext{
${ }^{1}$ José Antonio Miranda (2020) The country-of-origin effect and the international expansion of Spanish fashion companies, 1975-2015, Business History, 62:3, 488-508, DOI: $10.1080 / 00076791.2017 .1374370$

${ }^{2}$ This work was supported by the Ministry of Economy and Competitiveness of the Government of Spain and the European Regional Development Fund under Grant HAR2015-64769-P.
} 
fashion products. Despite the promotion campaigns carried out by successive Spanish governments, there is no a prestigious international image of Spanish fashion comparable to Italy's, and Spanish fashion companies find no advantage in indicating their country of origin.

This paper analyses the evolution of the Spain brand and the development of the main Spanish fashion companies to explain, firstly, the strategies used by these companies to counteract the lack of a positive country-of-origin effect that supported their penetration in foreign markets and, secondly, why the success of these companies has not led to a substantial strengthening of Spain's image in the fashion sector. Therefore, the contribution of the article to the existing literature on the country of origin effect is to show that, even in sectors as sensitive to this phenomenon as fashion, companies can develop successful strategies to erase this effect or to compensate the lack of a positive effect. The article also confirms that the construction of a country brand is a complex and long-term process, in which the strategy adopted by the companies of the country that operate abroad is decisive.

The business history literature has dealt with the country of origin effect focusing mainly on the study of industries that have been supported in the international market by the existence of a country brand with strongly positive connotations. For example, the works of Véronique Pouillard explore the organisation of haute couture when Paris was the undisputed world capital of fashion, and they show how institutions such as the Chambre Syndicale de la Couture tried to protect designs and brands of the haute couture houses against imitations and promoted the creation of a national brand to strengthen the French identity of this industry ${ }^{1}$. Lourdes M. Font has also analysed the international expansion of haute couture in the late nineteenth and early twentieth centuries, in a context determined by the predominance of France in world fashion ${ }^{2}$. On the other hand, Giorgio Riello has studied the success of French footwear in the British market in the first half of the nineteenth century, supported as well, among other factors, by the positive connotations of the geographical origin of these products ${ }^{3}$.

For other countries and other industries, Per H. Hansen has demostrated that the penetration of the Danish furniture industry in the global market was hand in hand with the construction of Danish Design as a well-known international brand since the interwar period $^{4}$. Pierre-Yves Donzé has analyzed the growth, the entry into the Asian market and the transformation of the main brands of the prestigious Swiss watch industry ${ }^{5}$. Geoffrey Jones has pointed out the strong influence of the country of origin effect in the perfume 
and cosmetics industries, which was decisive for the international expansion of French and American companies ${ }^{6}$, while Maki Umemura has explained that the lack of success of Japanese cosmetics companies outside the Asian market was mainly due to the marketing and branding strategy of these companies, which has been influenced by the fact that Japan did have a positive image for its fashion and beauty products in Asia but not globally ${ }^{7}$.

However, the country brand most directly studied by business history researchers has been the "Made in Italy". It is not possible to mention here the numerous works that have dealt with the development of Italian fashion, so I will limit myself to simply pointing out some of those that are closest to the study of the influence of the country brand in the conquest of foreign markets. Among them are the works of Marco Belfanti, Ivan Paris and Nicola White on the origin of the "Made in Italy". The first highlights the leadership of some designers and entrepreneurs in the international launch of Italian fashion and how the legacy of the Renaissance was used for the commercial promotion and cultural legitimation of this fashion ${ }^{8}$. Paris looks in depth at the strategies of direct promotion used (missions abroad, fashion shows, exhibitions...) ${ }^{9}$, while White discusses the key role played by the United States in the development of the Italian Fashion Style ${ }^{10}$. Elisabetta Merlo, alone and in collaboration with other authors, has investigated how Milan became one of the world capitals of fashion and the close relationships between industrial firms and fashion designers on which this process was based ${ }^{11}$. Valeria Pinchera has explored the role of Florence, and Cinzia Capalbo of Rome, in launching Italian fashion as an international phenomenon ${ }^{12}$. For his part, Giovanni Luigi Fontana has shown how the footwear industry was a prominent component in the international success of "Made in Italy"13.

All of these papers have dealt with international success stories supported by strong and positive country of origin images, globally or in certain regions. They are also cases in which the foreign success of the country's companies contributed directly to strengthening the positive connotations of the country brand. However, this article deals with a case of international success in the fashion sector that has not been matched by the construction of a leading country brand. Therefore, the main contribution of this research to the business history literature is to show a different way of successful development within fashion industries, and to analyse its conditioning and characteristics.

The methodology used has been to contrast the evolution of the image of Spain and Spanish fashion abroad with government policies to influence this image and with the 
competitive strategy followed by the main Spanish fashion companies. The period analysed ranges from the mid-1970s to 2015, that is, from the beginning of the crisis that prompted a new competitive strategy among Spanish fashion companies until the most recent year with reliable data. This chronology tries to cover the whole process of birth, development and international success of Spanish fashion companies.

The paper begins with a review of the literature on the "country of origin effect" on the evaluation of products by consumers. Subsequently, it shows how the image of Spain abroad has evolved and the policies that have been applied by the Spanish government in order to influence this image. The third section evaluates the measures adopted by the State to promote Spanish fashion. Then it examines the development and internationalization processes of the leading Spanish companies in the sector. Finally, conclusions are drawn.

\section{The country of origin effect}

The effect that the country of origin of a product can have on how consumers assess this product, on their decision to buy it and on the price that they are willing to pay for it, is a topic that has received much attention from marketing researchers ${ }^{14}$. International business literature has also been concerned, albeit to a lesser extent, with the way in which the characteristics of the country of origin influence the strategy of companies operating abroad ${ }^{15}$. Currently, it is widely accepted that the country of origin of a product influences, either positively or negatively, the perception that consumers have of the product and, therefore, their attitude towards it and their intention to purchase it as opposed to other competing products ${ }^{16}$. However, there are significant differences between the studies with respect to the degree of influence that they attribute to this variable. It seems clear that the influence of the country with which a product is associated depends largely on the type of good, the demographic, socio-economic and cultural characteristics of the consumers and the strength of the brand under which the product is marketed. The country of origin tends to be more highly valued in the purchase of consumer durables and luxury goods and services. The most influential consumer characteristics are the socio-economic and education level, age, product knowledge and involvement in the purchase. The greater the involvement and the greater the objective knowledge of the purchase, the lower the influence of the country of origin, and given that young consumers are more involved in the purchasing process than older consumers, this means that the influence of country of origin increases with age. It also seems that 
consumers with a higher socio-economic level are more aware of the image of the country of origin. With respect to the relationship between the brand of a product and the country of origin effect, the latter is weaker when the brand is strong and vice versa. The brands that are well-known by consumers are indicators of the quality and other characteristics of the product and are more influential than the country of origin. However, although to varying degrees, the image of the country influences the perception of the brands associated to this country. In turn, the most well-known brands of a country contribute decisively to shaping the image of this country.

In fact, the country of origin effect can be caused by both the generic image of the country and the specific image of the products of this country. The image of a country is what people think about this country, due to what they know about its political, economic, legal and cultural situation, or due to their experiences related to it. Therefore, it comprises a series of their beliefs and impressions of the place, a mental construction that is composed of cognitive facets, but also affective and regulatory aspects, and influences the evaluation of the products associated with the country. A positive image of a country helps the companies of this country to enter and prosper in external markets, while a negative image hinders this ${ }^{17}$.

Some literature on international business also stresses the importance of how governments react to the country of origin of companies operating in their territory. Governments give preferential treatment to companies from countries with which there are collaboration agreements, historical friendship ties, good political relations or that can provide desirable resources. In addition, the characteristics of the home country influence the resources firms develop and these resources affect the choice of the markets where companies operate and can help them to take advantage over other competing companies, both foreign and domestic ${ }^{18}$.

The image of a country has a particularly favourable impact on consumer decisions when it coincides with the positive characteristics that these consumers seek in a product. When consumers have a precise image of a product from a country, this image directly acts as a source for inferring the quality of the product, and therefore, influences their purchasing decision. In this case, the image of the country has an indirect influence through its impact on the image of the product. However, when consumers do not have this precise image of a product, the image of the country may replace it and become a direct indicator of quality for consumers ${ }^{19}$. 
Many studies have analysed the country of origin effect on fashion consumption. The results vary depending on the characteristics of the products and the consumers. In some cases, no clear influence of this variable has been found, but on the whole, it has been observed that the country of origin significantly affects the quality assessment made by consumers ${ }^{20}$. Similarly to other goods, fashion articles from developed countries tend to be regarded as having a higher quality than those coming from more backward countries, and the products of some countries, such as Italy and France, have special prestige $^{21}$.

The influence of the country with which the brand is associated is greater in the case of luxury products. It is no coincidence that the majority of the luxury fashion brands come from a few countries, including Italy and France, which account for more than half of all of these brands and which are internationally perceived as leading countries in the fashion industry. This image, that was the outcome of a long historical process ${ }^{22}$, provides the French and Italian fashion companies with a significant competitive advantage.

\section{The weakness of the made in Spain label}

The made in Italy label is an excellent visiting card in the fashion world, which consumers associate with products of a high quality and stylish design. This positive image is based on the historical tradition of luxury artisans and the extraordinary artistic heritage of Italy, which intensified and began to be disseminated internationally in the 1950s thanks to different initiatives to promote fashion ${ }^{23}$. In contrast, Spanish fashion companies have never had a prestigious country image with which to support the penetration of their products into foreign markets. The Spain brand has no clear, positive and cohesive international position, so these companies have often concealed their Spanish origin.

Over the last fifty years, Spain has undergone a profound modernisation process and has experienced considerable economic growth which, since the mid 1970s, has gone hand-in-hand with an opening up to international markets, social modernisation and political democratisation. Despite having been seriously affected by the recent Great Recession, Spain is currently one of the world's leading economies. In the global ranking it holds the 16th position in terms of the size of its GDP, the 12th in terms of its export of goods and 11th in terms of the value of its international investments. However, the international image of Spain does not correspond to these economic data. In the Country Brand Index of 2015, Spain held the 23rd position, and in the study recently carried out 
on the image of Spain by the Elcano Royal Institute, the overall evaluation received by Spain was much lower than that obtained by the other European countries considered in the study, except for Greece ${ }^{24}$.

Not only does Spain's image currently have a low evaluation, but its positive attributes are mainly emotional. Although the image of Spain is not perceived exactly the same in all regions of the world, and the knowledge of the country is much less in the United States or China, for example, than in Europe, in general Spain is seen as a country of leisure and fun, interesting because of its traditions and openness. The economic, technological and business aspects, however, are viewed less positively. The low overall assessment is highly influenced by the recent economic crisis, but the biased image of the country has been inherited from the past. After Spain's international isolation during the first decades of the Franco dictatorship, in the 1960s a tourism promotion campaign was carried out, supported by the slogan "Spain is different", which revived the romantic archetype created in the nineteenth century of an exotic and backward country ${ }^{25}$. The transition to democracy from 1976 significantly improved how Spain was seen abroad, particularly in political and institutional aspects, but at the beginning of the 1980s this image was still associated to economic backwardness and international consumers were unfamiliar with Spanish products and brands ${ }^{26}$.

The image of Spain improved substantially from the mid 1980s, with the country's entrance into the European Community and its economic progress. This improvement was reinforced by the successive promotional campaigns carried out by the Spanish government from the 1980s together with large international events, such as the Football World Cup in 1982 and the Barcelona Olympic Games, the Universal Exposition of Seville and the $5^{\text {th }}$ Centenary of the discovery of America in 1992. Spain modernised and strengthened its international image, particularly in Europe, with the intention of increasing its attractiveness as a tourist destination. However, the main features of this image continued to be of an emotional nature, while little progress was made in associating the name of Spain with quality, efficiency and technology. According to the Brand Asset Valuator study, carried out by the marketing and communication multinational Young \& Rubicam in 2000, Spain was considered to be a country with deficiencies in terms of quality, confidence, value for money and innovation, both in Europe and the United States. No significant progress was made in the diffusion of Spanish brands and products, or the valuation of these products. According to the study carried out in 1996 by the Ortega y Gasset Institute, 70\% of those surveyed in the four 
European countries considered did not know any Spanish brands and did not identify Spain with any specific products or skills. The Bozell-Gallup survey, carried out in the mid 1990s among over 20,000 consumers in 17 countries, reveals that only $10 \%$ of those interviewed gave a positive valuation of Spanish products, while $22 \%$ assessed them negatively ${ }^{27}$.

With the objective of updating and strengthening the international image of the country, the Spanish government implemented the Proyecto Marca España (Brand Spain Project) at the end of $2001^{28}$. However, the Project was pushed into the background due to the change in the ruling party after the elections of 2004. The new government focuses the strategy on improving the image of some products in certain countries considered priority markets. One of the most prominent was the so-called Made in/Made by Plan, to support Spanish companies in the United States, developed by the ICEX (Spanish agency for the promotion of investment and exports) in 2009 and 2010, with a budget of 44 million euros ${ }^{29}$. Although these actions were limited in terms of sector, geography and budget $^{30}$, in their early years they coincided with a highly positive economic climate for Spain, with rapid GDP growth and the international expansion of some of its large companies, which gave rise to a rapid improvement of the country's image. In the Country Brand Index of 2007, Spain held the seventh position and was the fourth best-placed European country, only behind the United Kingdom, France and Italy.

However, the confluence of the effects of the international Great Recession with the bursting of Spain's property bubble generated a serious crisis in Spain from 2009. Spain's GDP fell sharply in 2009 and 2012 and the income per capita fell from being above the average of the European Union to being below this level after 2010. The unemployment rate shot up to above $25 \%$ in 2013 , the public deficit increased rapidly, particularly in 2009 and 2012. Furthermore, the European Union had to bail out part of the Spanish financial system. This negative economic evolution generated a serious decline in the image of Spain, which was progressively transferred to the international classifications. In the Country Brand Index, Spain's position fell from 7th in 2007 to 23rd in 2014.

In order to address the deterioration of the external image of the country, the new government emerging from the 2011 elections resumed the Brand Spain Project and in June 2012 created the High Commission of the Government for the Spain Brand, responsible for the planning, promotion and coordinated management of the actions of all the public and private entities involved in the promotion of the external image of 
$\operatorname{Spain}^{31}$. The Commissioner had a rank equal to secretary of state, but he did not have its own budget and was supported by a very low level of staffing. The new institution had three fields of action: First, the establishment of mechanisms for analysing and monitoring the image of Spain. To do this, the Spain Brand Observatory was created within the Elcano Royal Institute, with the objective of conducting a rigorous and systematic monitoring of this image. Second, the coordination and stimulation of public and private actions to promote Spain abroad. And finally, the creation of systems for communicating and disseminating the positive aspects of Spain.

However, the actions developed over the last few years to improve Spain's image seem to have had little success so $\operatorname{far}^{32}$. The promotional campaigns have been harshly criticised by some experts who believe that they take the wrong approach, lack credibility and are uncoordinated ${ }^{33}$.

\section{Policies to promote Spanish fashion}

Government efforts to improve the country's image were accompanied by specific campaigns to promote Spanish fashion abroad. The first major campaign with this objective was the Plan for Promoting Design and Fashion which began in 1985 and was linked to the Textile Reconversion Plan. At the beginning of the 1980s, the Spanish textile industry had a production structure that was technically backward and which was too large for the new environment of economic openness in which the country was immersed. The severe crisis experienced by the companies in the sector led the Spanish government to approve a Textile Reconversion Plan which, together with the socio-labour readjustment measures, contemplated a whole series of actions to stimulate the improvement of production, financial and commercial structures in order to facilitate the adaptation of supply to the variations in demand, renew the technology and increase competitiveness through design, fashion brands and quality ${ }^{34}$.

From 1984, the government wished to further boost the improvement in the creativity and quality of the Spanish textile-clothing sector, increasing its value added and preparing it to compete in the international market. To do this, the Plan for Promoting Design and Fashion was approved in 1985 and was in force until the end of $1988^{35}$. This new Plan contemplated the continuity of the support for the projects aimed at promoting design and fashion presented by individual firms, while introducing a specific legal framework to support collective and institutional projects. An investment of more than 18 billion pesetas (256 million euros of 2017) was forecast for the period between 1984 
and 1988. Among the actions developed we can highlight the creation of the Gaudí Fashion Week in Barcelona and the Cibeles Fashion Week in Madrid, the foundation of the Design and Fashion School in Madrid and the "Moda de España" advertising campaign, focused on spreading the image of Spain as a country that created fashion and the importance of fashion for the industrial development of the country ${ }^{36}$.

In 1988, a Plan for Promoting Design Quality and Fashion for the Small and Medium-sized Enterprises was created, which also extended the actions to the leather and footwear, jewellery and costume jewellery, toy, ceramics and furniture industries. The new plan required an investment of around 10 billion pesetas (more than 140 million euros of 2017) for the period 1988-1991 and, contrary to the previous plan, which had focused on highlighting the figure of the creators, it basically sought to reinforce the leading companies in the different sectors of the fashion industry in order to generate carry-over effects in their respective fields ${ }^{37}$. Overall, these plans in the 1980s were successful as they significantly improved the image of Spanish fashion and the knowledge of the country's designers in the domestic market ${ }^{38}$.

In the 1990s, other programmes to aid the textile and clothing industries were adopted, but they had a much lower budget and were less focused on diffusing Spanish fashion. It was not until the twenty-first century that another programme to promote Spanish fashion was launched, namely the Plan Global de la Moda (Global Fashion Plan), aimed initially at the textile, clothing and footwear sectors, although it was later extended to the leather goods, costume jewellery and cosmetics industries. The Plan was designed for a period of four years from 2002 to 2005, with a budget of 48 million euros ${ }^{39}$, but it was extended until 2007 and the total expenditure amounted to over 65 million euros $^{40}$.

The objective of the Plan was to reinforce the image of Spanish fashion abroad and to promote the export of the products from the clothing sector. The promotional tasks in foreign markets were undertaken by the ICEX, which implemented the Proyecto España Moda (Spain Fashion Project) comprising a series of actions that had been agreed with the representatives from the private sector who were involved in the plan. The project was based on three strategic pillars: training, promotion in external markets and the creation of an international image. It sought to disseminate the image of Spain as a country that creates fashion, in order to enable the most successful Spanish companies to identify themselves with the "Made in Spain" brand. The specific measures applied included the implementation of a communication and advertising plan of Spanish fashion 
in foreign markets, the organisation of visits to Spain by buyers, journalists and international fashion experts, the promotion of Spanish fashion shows abroad, supporting the participation of Spanish firms in the major international fashion shows and the organisation of official exhibitions and group participation in fairs in other countries, the adaptation of ICEX business programmes to the fashion sector, the organisation of courses on foreign markets, the training of specialists in the foreign trade of fashion products and the creation of an electronic Spanish fashion portal (fashionfromspain) ${ }^{41}$.

After the Global Fashion Plan, the ICEX initiated the Plan for the International Promotion of Spanish Fashion ${ }^{42}$, which consisted in continuing to support the participation of Spanish companies in international fairs, the organisation of fashion shows, the fashion portal www.fashionfromspain.com and the undertaking of advertising campaigns in countries considered to be strategic markets, although with a lower budget $^{43}$. In addition to these efforts developed by the central government, as from the 1980s, the governments of the different Spanish autonomous regions also carried out actions to support the fashion industries in their territories, particularly in those regions where these industries were highly concentrated, such as Galicia, Catalonia and the Region of Valencia. These promotional policies carried out by the regional governments have followed their own strategies and have not been coordinated with the policies of the central government.

However, despite these initiatives, the "made in Spain" label continued to add very little value to the products in the fashion sector. According to a study carried out by Interbrand in 2009, Spanish fashion was unknown internationally, and therefore, the association between the Spain brand and fashion was very weak. The few Spanish brands with a significant presence in foreign markets were not recognised as being Spanish by many consumers and, although the "made in Spain" fashion articles had a positive connotation as they came from Europe, they were less highly valued than "made in France" or "made in Italy" products ${ }^{44}$.

\section{The international expansion of Spanish fashion companies}

The textile and clothing industries grew rapidly in Spain during the 1960s and beginning of the 1970s, driven by the increase in internal demand and highly protected from foreign competition. This growth, however, was based on a technologically backward production structure in which there was a predominance of small firms that were labour intensive, with low productivity levels and limited specialisation ${ }^{45}$. 
Therefore, despite the low wages and the incentives provided by the State, the Spanish products were not competitive internationally and textile and clothing exports did not reach large volumes. In 1974 the value of the exports of these types of goods was almost eight times higher in Italy than in Spain.

In the second half of the 1970s and the early 1980s, the textile and clothing industries were severely affected by the international economic crisis and external competition, which increased after Spain entered the European Community in 1986. Employment and production fell dramatically and many companies began to operate in the informal economy. In order to facilitate the modernisation of the sector and its adaptation to the new environment of international competition, the Spanish government approved the Textile Reconversion Plan in 1981, which was followed by the Plan for Promoting Design and Fashion in the second half of the 1980s and the Textile-Clothing Competitiveness Plans in the 1990s.

The effective integration of Spain into the European Community in 1986 implied the end of the export promotion policy that had been applied until then and a substantial reduction of the tariff barriers. Both of these phenomena reduced the competitiveness of the Spanish industry, which was also impaired by the appreciation of the peseta against other currencies. Spanish wages were lower than those of the more developed European countries, but higher than those of developing countries and even those of other competitors in southern Europe, such as Portugal. Furthermore, the Spanish companies had less experience in the international market and a level of design and fashion development that was much lower than that of the companies in other European countries, particularly France and Italy. Therefore, the imports of textile and clothing products shot up, both in the low price segment from developing countries and in the high quality segment, mainly from other countries in the European Community. Exports, in contrast, increased much more slowly. The situation of the sector was worsened by the fall in demand due to the overall economic crisis at the beginning of the 1990s.

However, from 1994 there was strong export growth based on the devaluation of the Spanish currency and the containment of wage increases. In the textile industry, exports grew more slowly after 1999 and then shrank with the crisis of 2008. In the clothing sector, however, the boom in exports accelerated even more from 2001 and, although they decreased sharply between 2008 and 2010 due to the international recession, they began to grow again in 2011. The recovery of the international competitiveness of these industries was based on a profound technological renovation 
process, which began in the 1980s, and on the progressive specialisation in high quality products with a greater value added. In the subsector of knitted goods, for example, production per worker practically doubled between 1984 and 1994, substantially reducing the difference in productivity with respect to Italy ${ }^{46}$. The modernisation of all of these fashion industries was favoured by their high concentration in a few highly specialised industrial districts, where the existence of Marshallian external economies facilitated the transformation of the product and the adaptation to the new market conditions ${ }^{47}$. A delocalisation process of the most labour intensive activities also took place; first towards other Spanish regions with lower wages; then towards nearby countries with even lower labour costs, such as Portugal, Morocco, Tunisia or Turkey and, in a third phase, towards China and other countries in the Far East.

The large exporting efforts of the Spanish firms were largely made in response to the difficulties that they were experiencing in the domestic market. On the one hand, due to the limited size of this market, where the per capita consumption of clothes represented less than $40 \%$ of the level in Germany, the United Kingdom, France or Italy. On the other hand, due to the strong import penetration. Despite the growth of exports, the textileclothing sector continued to have a trade balance deficit in Spain and the increase in domestic consumption did not prevent the progressive decrease in clothes production after the second half of the 1990s. Meanwhile, textile production continued to grow until the end of the twentieth century, but fell sharply after 2002. In addition, except for the second half of the 1990s, in both industries the labour force reduced at a constant rate and by 2014 the number of workers was just one third of those in 1990. The cause of this setback was the unstoppable progress of imports from Asia, due to the progressive reduction of restriction quotas for these imports from the mid 1990s, as stipulated in the GATT Uruguay Round Agreement on Textiles and Clothing, which led to the complete liberalisation of this trade in 2005, and due to the entry of China into the World Trade Organisation at the end of 2001. Once again, the State had to launch plans to support the sector: in 2000 the Competitiveness Plan was approved for the textile-clothing sector; in the following years specific actions of the Technical Research Promotion Programme were put into practice for these industries; and in 2006 a new Support Plan was initiated for the sector with socio-labour measures aimed at reducing the impact of job losses and with industrial and financial measures to improve the competitiveness of firms ${ }^{48}$.

In response to the high level of competition in the Spanish market, since the 1980s, some companies opted to enter the distribution business, creating commercial chains and 
assuming the control of the whole cycle of the product, from the design and manufacture to the marketing and distribution, although externalising many of the phases of the production process or subcontracting all of the manufacturing process in other countries. These companies that underwent forward vertical integration and others that were created with no manufacturing facilities, engaging only in the design and marketing of the product, they initially operated on the domestic market, but soon began to expand into other countries. The internationalisation process is a very recent phenomenon as the majority of the brands that currently can be found in many countries around the world did not start their penetration into foreign markets until the 1990s and the process did not accelerate until the end of the decade.

The strategy of these companies has been to respond to the growing competition in the sector by specialising in medium-low priced clothing, but with an attractive design that follows the fashion trends, and by increasing the flexibility in their production and the speed of adapting to market demand through organisational and technological innovations. These companies started to renew their products more and more frequently and now they are constantly launching new collections throughout the year, in very short production cycles. This is the so-called "fast fashion". In order to adapt the articles to the latest trends, the most successful companies have organised a very fast creation and manufacturing process, which enables them to imitate the style of the clothes exhibited in the major fashion shows and launch the product a few weeks later. In some cases, market research is carried out whereby short series are created and then produced in a very short time depending on how the demand responds ${ }^{49}$.

There are very few Spanish fashion companies that have achieved a truly strong presence in the international market. Only four companies (Inditex, Mango, Cortefiel and Desigual) exceed or are near to reaching an annual turnover of one billion euros, and only eight more clothing companies exceed 100 million euros (see table 1). In fact, the success of Spanish fashion is fundamentally the success of Inditex, which is currently the number one fashion retailer in the world. Its turnover figures, employment and the size of its retail network are more than three times the sum of the 11 Spanish companies that follow it. Furthermore, to a large extent, the development of these other companies has been based on the imitation of the strategies of Inditex and has benefitted from the favourable business environment for these types of companies created in many countries by the prior success of the Galician fashion group. Therefore, we shall focus the analysis on a company level on the cases of Inditex, the pioneer and leading company, and on Mango 
which is an example of the companies that have imitated the strategy of the Galician group while incorporating their own features.

\begin{tabular}{|c|c|c|c|c|}
\hline \multicolumn{5}{|c|}{ Clothing companies } \\
\hline Company & Chains & $\begin{array}{c}\text { Year of } \\
\text { establishment }\end{array}$ & $\begin{array}{l}\text { Turnover } \\
\text { (millions } \\
\text { of euros) }\end{array}$ & Workers \\
\hline Inditex & $\begin{array}{l}\text { Zara, Massimo Dutti, Bershka, } \\
\text { Pull\&Bear, Stradivarius, Oysho, Zara } \\
\text { Home, Uterqüe y Lefties }\end{array}$ & 1963 & 20,900 & 152,854 \\
\hline Punto Fa & $\begin{array}{l}\text { Mango, Mango Man, Mango Kids y } \\
\text { Violeta }\end{array}$ & 1984 & 2,327 & 15,793 \\
\hline Cortefiel & $\begin{array}{l}\text { Spirngfield, Women'secret, Cortefiel y } \\
\text { Pedro del Hierro }\end{array}$ & 1880 & 1,095 & 10,592 \\
\hline Desigual & Desigual & 1984 & 933 & 4,200 \\
\hline Pepe Jeans & Pepe Jeans y Hackett & 1973 & 538 & 2,500 \\
\hline $\begin{array}{l}\text { Sociedad } \\
\text { Textil Lonia }\end{array}$ & $\begin{array}{l}\text { Purificación García y CH Carolina } \\
\text { Herrera }\end{array}$ & 1997 & 307 & 2,500 \\
\hline Mayoral & Mayoral & 1941 & 325 & 1,200 \\
\hline Pronovias & Pronovias & 1922 & 150 & 850 \\
\hline Punt Roma & Punt Roma & 1976 & 150 & $\overline{1,179}$ \\
\hline $\begin{array}{l}\text { Liwe } \\
\text { Española }\end{array}$ & Inside & 1973 & 141 & 1,439 \\
\hline Comdifil & $\begin{array}{l}\text { Shana, Double Agent, Friday's Project y } \\
\text { SHN }\end{array}$ & 2010 & 141 & 900 \\
\hline $\begin{array}{l}\text { Adolfo } \\
\text { Domínguez }\end{array}$ & Adolfo Domínguez & 1976 & 108 & 1,419 \\
\hline
\end{tabular}

Thanks to an exemplary application of the fast-fashion competitive strategy, Inditex has been the leading clothes retailer in the world since 2013, with sales in 2015 of almost 21 billion euros and a market value of 94 billion euros, $927 \%$ higher than when it was listed on the stock exchange in May $2001^{50}$. Its founder, Amancio Ortega, began his career in the clothing sector as a sales assistant in several of the leading clothes stores in A Coruña, a medium-sized city in northeastern Spain, at the end of the 1950s. With the experience and contacts that he acquired, he began a modest production of dressing gowns and underwear. The next step was the founding of Confecciones GOA in 1963, which was engaged in the manufacture of ladies underwear and clothes. This was followed by other companies also located in A Coruña. The group also entered the retailing business when it opened its first Zara store in A Coruña in 1975 for the sale of mid-range clothing. Soon the chain extended with other stores in the city and the rest of the region ${ }^{51}$. 
At the beginning of the 1980s, Ortega took the leap into the national market. To do this he incorporated qualified professionals into the management team, increased the production capacity, externalised the sewing of garments to independent workshops and cooperatives, and located Zara stores in the best shopping areas of the main Spanish cities. In 1985 he founded Industria de Diseño Textil SA (Inditex), a new parent company to control his group of companies, which comprised seven clothing companies, one thousand workers and 41 stores, with a turnover equivalent to 87 million euros. At the end of the 1980s the company began to penetrate foreign markets, first in Portugal (1988) and then in the United States (1989) and France (1990). However, it was during the following years that the real international expansion of the group took place and by the end of the twentieth century Inditex had a presence in 33 countries with more than 1000 stores and its turnover exceeded 2.6 billion euros, of which more than half was earned in foreign markets (table 2).

\begin{tabular}{|c|c|c|c|c|c|c|}
\hline Year & $\begin{array}{l}\text { Sales } \\
\text { (millions of } \\
\text { euros) }\end{array}$ & $\begin{array}{l}\% \text { of sales } \\
\text { abroad }\end{array}$ & $\begin{array}{l}\text { EBTDA } \\
\text { (millions of } \\
\text { euros) }\end{array}$ & $\mathrm{N}^{\circ}$ of stores & $\begin{array}{l}\mathrm{N}^{\circ} \text { of } \\
\text { workers }\end{array}$ & $\begin{array}{l}\mathrm{N}^{\circ} \text { of } \\
\text { countries } \\
\text { with stores }\end{array}$ \\
\hline 1994 & 756 & 25 & 140 & 424 & 5,018 & 8 \\
\hline 1997 & 1,217 & 42 & 254 & 622 & 10,891 & 14 \\
\hline 2000 & 2,615 & 52 & 521 & 1,080 & 24,004 & 33 \\
\hline 2003 & 4,599 & 54 & 873 & 1,922 & 39,760 & 48 \\
\hline 2006 & 8,196 & 60 & 1,790 & 3,131 & 69,240 & 64 \\
\hline 2009 & 11,084 & 68 & 2,374 & 4,607 & 92,301 & 74 \\
\hline 2012 & 15,946 & 79 & 3,913 & 6,009 & 120,314 & 86 \\
\hline 2015 & 20,900 & 82 & 4,699 & 7,013 & 152,854 & 88 \\
\hline
\end{tabular}

Although at the beginning of the 1990s loans were widely used to finance this expansion, from the middle of this decade the company began to reduce its debt, financing its growth mainly with the reinvestment of earnings ${ }^{52}$. The international expansion was fast until the economic crisis of 2007, after which it continued at a more moderate rate. In 2007, Inditex had almost 3,700 stores distributed over 68 countries, the number of workers was close to 80,000 and its turnover was almost 9,5 billion euros of which $63 \%$ corresponded to sales outside of Spain. Eight years later, the sales figures and the number of stores and workers had practically doubled, $88 \%$ of revenue came from abroad and the company had extended its retail network to 88 different countries (table 2). Europe has remained the principal market and in 2015 it still accounted for $62 \%$ of the group's sales, 
although America, with 15\% and Asia with $20 \%$ have increased their weight, particularly after 2009. China has become the second largest market for the group in terms of the number of stores.

Currently, the Inditex group is composed of almost three hundred companies engaged in manufacturing, logistics and retail distribution, and is structured into eight retail brands aimed at different demand segments (Zara, Pull\&Bear, Massimo Dutti, Bershka, Stradivarius, Oysho, Zara Home y Uterqüe). These brands do not use words that evoke the Spanish origin of the company and Inditex does not carry out any actions to identify them as Spanish. The country of origin is ignored in order to achieve the image of global brands, since the link with the brand Spain does not bring positive connotations in the world market of fashion products. According to a survey performed by the Spanish Leading Brands Forum, less than a third of foreign consumers identified the Zara brand as Spanish and a high percentage of them thought it was Italian $^{53}$.

The competitive advantage of Inditex is principally based on the flexibility of its production and the efficiency of its logistics system, which enables it to adjust its supply to the demand much faster and to continually introduce new products ${ }^{54}$. The vertical integration of the group greatly contributes to this flexibility, shortening the time between the design of the article and its manufacture as, contrary to some of its main competitors, Inditex does not only design and sell its clothing, externalising its production to far away countries with low costs but, for highly fashionable garments that need to be made quickly, it also undertakes a large part of the manufacturing process itself or contracts nearby cooperatives and companies in Galicia and Northern Portugal.

Flexibility is also achieved through the use of avant-garde technology in its production processes (with the robotization of the design and cutting phases from the beginning of the 1990s), in the connection between the head office and the points of sale (using the technological advances in information and communication) and in logistics (with the automation of the eight large warehouses located in different parts of Spain) and through the autonomous operation of the different retail brands of the group.

Another key source of Inditex's competitive advantage is the adaptation of its products to the taste and needs of the consumers. To achieve this it has a team of designers who visit the principal international fashion shows and it also uses "trend spotters" who observe the consumption of their potential clients ${ }^{55}$. Furthermore, the company uses its stores as a daily source of detailed information about the evolution of demand through electronic systems which have progressively been perfected. On the other hand, the 
existence of the different brands of the group enables it to gain a very wide spectrum of consumers, who are driven to frequently visit the stores due to the high rotation of products, while the careful selection of the points of sale and the careful window dressing guarantees the public visibility of the brands without large investments in advertising. In fact, while its main international competitors spend more than $5 \%$ of their revenue on advertising, Inditex only spends $0.3 \%$.

Mango, a family business group with the corporate name of Punto Fa SL, is Spain's second largest fashion exporter. In 2015, its sales exceeded 2.3 billion euros, more than $80 \%$ of which came from abroad, mainly from other European countries (42\%). It employs 16,000 workers and has more than 2,700 points of sale distributed over more than one hundred countries (table 3). The origin of the company dates back to 1984, when Isak Andic, of Turkish descent but a resident of Barcelona since the age of 13, together with his brother Nahman, opened their first store in Barcelona, with the name Mango, to sell imported ladies clothing. The following year they had five stores in Barcelona and began to expand throughout the rest of Spain $^{57}$.

Until the mid 1990s, the company focused on consolidating its business in Spain, defining the concept of the product, the type of store and the brand image, adopting a justin-time system and extending the retail network. In 1993, it had one hundred points of sale in the country. At this time, the brand also began to explore the external market through franchises. The first stores established abroad were in Portugal in 1992, followed by others in France, Andorra, Switzerland, Malta and Mexico in 1994 and Belgium, Greece, South Korea, Taiwan and Israel in 1995. At the end of this phase a total of 37 franchises had been created abroad ${ }^{58}$.

However, it was after 1996 when Mango truly focused on its international expansion, complementing the franchises with the creation of its own stores. By 1997, foreign sales exceeded those in Spain and at the end of the twentieth century the brand's stores were present in almost fifty countries. Measured in current euros, sales doubled between 2000 and 2008, and doubled again between 2008 and 2015. In this second phase, the company has invested heavily in the development of its logistics system to improve its information and to increase its reaction speed to changes in demand. Its supply has diversified with the incorporation of a line of complements in 2005, a line of men's fashion in 2008, new children's fashion brands, sports clothing and underwear in 2013, a line of large sizes for women in 2014 and baby clothes in 2015. It has also modified the characteristics of its points of sale with the introduction of large-sized stores in 2012. 


\begin{tabular}{|r|r|r|r|r|r|r|}
\hline \multicolumn{7}{|c|}{ Table 3. Indicators of the evolution of Mango, 2000-2015 } \\
\hline Year & $\begin{array}{c}\text { Sales (millions } \\
\text { of euros) }\end{array}$ & $\begin{array}{c}\text { \% of sales } \\
\text { abroad }\end{array}$ & $\begin{array}{c}\text { EBTDA } \\
\text { (millions of } \\
\text { euros) }\end{array}$ & $\begin{array}{c}\mathbf{N}^{\mathbf{o}} \text { of } \\
\text { stores }\end{array}$ & $\begin{array}{c}\mathrm{N}^{\mathbf{o}} \text { of } \\
\text { workers }\end{array}$ & $\begin{array}{c}\mathrm{N}^{\mathbf{o}} \text { of } \\
\text { countries } \\
\text { with stores }\end{array}$ \\
\hline 2000 & 548.1 & 60 & 105.8 & 515 & 4,657 & 49 \\
\hline 2002 & 744.9 & 69 & 124.3 & 629 & 4,729 & 69 \\
\hline 2004 & 831.7 & 71 & 158.9 & 768 & 5,453 & 75 \\
\hline 2006 & 942.3 & 74 & 197.0 & 995 & 5,901 & 90 \\
\hline 2008 & $1,100.7$ & 77 & 191.8 & 1,228 & 7,865 & 102 \\
\hline 2010 & $1,269.5$ & 81 & 186.9 & 1,757 & 8,690 & 109 \\
\hline 2012 & $1,690.9$ & 84 & 209.2 & 2,598 & 12,211 & 109 \\
\hline 2014 & $2,017.1$ & 81 & 223.2 & 2,741 & 15,793 & 109 \\
\hline 2015 & $2,327.0$ & 81 & 170.7 & 2,730 & 16,623 & \\
\hline Source: Annual reports of Mango. &
\end{tabular}

Mango has followed a strategy which increasingly resembles that of Inditex, but displays some significant differences with the Galician firm. First, from the outset, Mango has never engaged in its own production activities. The company designs the product and contracts its manufacture to other companies in which it has no participation and which do not work exclusively for Mango, although they usually have long-term relationships with it. Companies from the Far East constitute the main origin of Mango clothing, making around $70 \%$ of the garments. This geographical distribution of the suppliers is another difference with Inditex, for which Asia is also a principal source of suppliers but not to such an extreme as Mango, because it uses European suppliers to a greater extent.

The fact that Mango uses less geographically close suppliers explains why the production process and distribution cycles of the Catalan group's products are not as short as those of Inditex. The average time for the design, manufacture and distribution of the garments used to vary between 3 and 4 months $^{59}$. However, in 2015 the Catalan company announced a change in its strategy in order to be able to renew the collections in its stores every two weeks and during that year there was a significant increase in the production carried out in Europe and Turkey ${ }^{60}$.

Another difference with the majority of the brands of the Inditex group, although one which has been reduced in recent years, is that existing in the type of product and price. Although Mango began as a chain of affordable clothes, it progressively increased the quality and prices of its products, seeking to position itself in the medium-high segment, with prices that were higher than those of Zara, its most direct competitor. However, this business model began to show its limitations since 2008, with the 
international economic crisis, so, in 2012, the company began to substantially reduce its prices and in 2015 it created a new line of clothing for younger consumers with even lower prices ${ }^{61}$.

Mango also differs from Inditex in terms of the growth model of its retail network. While the Galician company has based its strategy fundamentally on own stores, the Catalonian company has largely used franchises for its international expansion, particularly outside of Europe. In 2005, only 30\% of Mango's points of sale were own stores, and in 2014, after several years of applying a strategy to increase the number of own stores, this figure was still below 40\%. In contrast, franchises account for just $13 \%$ of Inditex's stores. Of Mango's points of sale outside of Europe, 95\% are franchises (with the exception of Turkey where all of the more than one hundred stores are own stores), while in the case of Inditex, only 35\% of stores outside of Europe are franchises, most of them in Asia.

On the other hand, Mango began its online business much before Inditex and has developed it to a greater extent. Mango was among the first Spanish fashion companies to begin selling on the Internet in the year 2000 and in 2006 it created a virtual outlet store to complement its online collection. Furthermore, it has introduced its products into some of the principal online sales channels ${ }^{62}$. Currently, the e-commerce part of the business earns the company 234 million euros, almost $11 \%$ of its sales. Inditex, however, did not begin its online sales activity until 2007, when it began to apply it to Zara Home (its home textile chain). It did not introduce it into its main brand Zara until 2010 and it did not begin to use it in the rest of the brands of the group until $2011^{63}$.

\section{Conclusions}

The image of Spain abroad has traditionally highlighted the fun and festive features of the country, but has not associated it to efficiency, quality or modernity. The campaigns developed by the Spanish government to modify this situation have not been very effective because they have not had sufficient economic resources and have not been designed appropriately. Furthermore, they have not been maintained over time but have varied in accordance with the changes in political power and did not start until the mid 1980s, while studies on the subject indicate that constructing the image of a country is a long-term phenomenon. In addition, this transformation of Spain's image has been slowed and even reversed by the strong impact that the recent Great Recession has had on the country. 
The Spanish companies could not take advantage of a good international valuation of the country's fashion. Despite the fact that some good designers have emerged from Spain throughout history, Spanish fashion was unknown in the international market. The most famous Spanish fashion designer, Cristóbal Balenciaga, was, and continues to be, associated to French haute couture for which he worked for more than three decades. It is true that Spanish fashion has been supported by different promotion plans developed by the central government and by some initiatives implemented by the regional governments from the 1980s. This public action has had positive effects, mainly on the image of Spanish fashion in Spain itself. But it has not been enough. On the one hand, with the exception of the plans implemented in the 1980s, the budgets for these types of action have not been sufficient. On the other hand, they have lacked continuity over time, due to the variations arising from the changes in the political power. Finally, the promotional campaigns have been weakened by the lack of coordination between the actions of the central government and that of the regional governments.

Spanish companies have been able to overcome the disadvantage of a poor valuation of the "Made in Spain" label by blurring their Spanish origin. Their international advertising campaigns never mention their country of origin and many have adopted brand names that suggest a different origin, often Italian or Anglo-Saxon.

The Spanish companies have also countered the weakness of the "Made in Spain" brand by specialising in a new type of fashion that is valued not for the quality of the product and the elegance in the design, but for its innovation, differentiation and good price. As Spanish fashion brands are positioned in the medium-low market segment, they have a lesser need for prestige than for example the "Made in Italy" products. In fact, consumers do not seek high quality and elegance in the garments of the most successful Spanish brands. They look for originality and fashion at an affordable price. Furthermore, these consumers are, on the whole, young and highly involved in the purchase process, which is the type of consumer least influenced by the country of origin of the product.

On the other hand, these companies have compensated for the lack of positive connotations with respect to their origin by offering a global fashion unrelated to any specific country, but to a brand which takes advantage of the standardisation of tastes on a global scale arising from globalisation. The great strength of these fast fashion brands has also contributed to minimising the influence of the country of origin. Clothes from Zara are perceived as Zara fashion not Spanish fashion. 
The history of the internationalization process of Inditex and Mango shows that these companies made their expansion abroad regardless of the image of Spain. Their penetration in the different countries did not depend on the image of Spain in them, but on their geographical proximity, the degree of openness of their markets and the business opportunities that these countries offered. During the years of the recent Great Recession, while the brand Spain deteriorated rapidly, Inditex and Mango continued their impressive international expansion.

Therefore, what has occurred over the last two decades is not so much a success of Spanish fashion but a success of a few Spanish companies. These companies have broken away from the traditional production-oriented fashion model structured into seasons and have replaced it with a new model of fast fashion, where garments are continually renewed and it is now demand that orientates fashion. We should highlight the leadership of Inditex, which has been the key company in the development of this new model. Its example has not only guided the international expansion of other Spanish fashion companies, but has obliged the whole of the sector to evolve throughout the world.

However, the success of these companies has not been able to enhance the prestige of the "Made in Spain" label in the fashion sector for different reasons. First, because this success is a very recent phenomenon and, as previously indicated, the process of modifying the image of a country and the image of the products of a country usually require long periods of time. Second, because the leading companies follow a strategy of not referring to their Spanish origin and market themselves as global companies. Another important reason has been the specialisation of these companies in medium quality products with a low price, which does not evoke prestigious connotations.

In addition, the success of Spanish brands should not be exaggerated. Although more than several thousand Spanish companies in the fashion sector export their products, the immense majority of them are small companies that have a low impact on the international market. The firms that have achieved a significant presence are very few. Inditex, the world's leader in the sector is an exceptional case. The three Spanish companies behind Inditex with an annual turnover of one billion euros have a market share that is much smaller than that of the large international fashion groups and therefore are positioned much lower down on the world ranking. The success of the Spanish firms is notable due to its newness, the speed at which it has been achieved and the exceptional case of Inditex, but Spain does not dominate the international fashion market and 
therefore a sudden identification of the "made in Spain" label with prestigious fashion should not be expected.

\section{Notes}

\footnotetext{
${ }^{1}$ Pouillard, "Managing fashion" and "Design piracy".

${ }^{2}$ Font, "International couture".

${ }^{3}$ Riello, "La chaussure".

${ }^{4}$ Hansen, "Networks, narratives".

5 Donzé, "From the Industrial District" and "The transformation of global luxury brands"; Donzé and Fujioka, "European luxury".

6 Jones, "Blonde and Blue-Eyed?" and "Beauty Imagined".

${ }^{7}$ Umemura, "Reaching for global".

${ }^{8}$ Belfanti, "Renaissance and 'Made in Italy" and "History as an intangible asset".

${ }^{9}$ Paris, "Orígenes del Made in Italy".

${ }^{10}$ White, "Reconstructing Italian fashion".

${ }^{11}$ Merlo, "Le origini” and "Italian fashion business"; Merlo and Polese, "Turning fashion" and "Construire una capital"; Colli and Merlo, "Family business"; Belfanti and Merlo, "Patenting fashion".

12 Pinchera, "Firenze e la nascita"; Capalbo, "Da sartorie a case di moda".

${ }^{13}$ Fontana, "Scarpe d'autore".

${ }^{14}$ Usunier, "Relevance", 60-62.

15 Cuervo-Cazurra and Genc "Transforming disadvantages" and "Obligating, pressuring"; Cuervo-

Cazurra, "Global strategy"; Meyer, Mudambi and Narula, "Multinational enterprises".

${ }^{16}$ Rezvani et al., "A conceptual study", 207.

17 Wang et al., "Country image", 1041-1043.

${ }^{18}$ Cuervo-Cazurra, "Global strategy”, 383-384.

${ }^{19}$ Roth and Romeo, "Matching Product Category", 477-497.

${ }^{20}$ Vrontis, Thrassou and Vignali, "The country-of-origin effect", 463-469.

${ }^{21}$ Wall and Heslop, "Consumer attitudes", 337-358.

${ }^{22}$ White, Reconstructing Italian Fashion; Merlo and Polese, "Turning Fashion into Business”; Belfanti, Civiltà della moda; Merlo, "Le origini" and "Italian fashion business"; Paris, "Orígenes del Made in Italy"; Font, "International couture"; Pouillard, "Design Piracy" and "Managing fashion"; Pinchera, "Firenze e la nascita"; Capalbo, "Da sartorie a case di moda" and "Creativity and innovation".

${ }^{23}$ Belfanti, "History as an intangible asset", 74-90. On the corporate strategy of Italian fashion companies see Merlo, "Italian fashion business", 344-362.

${ }^{24}$ Real Instituto El Cano, Barómetro, 6.

${ }^{25}$ Vangehuchten and Crespo, "Reinventar la Marca España", 6.

${ }^{26}$ Morello, "The 'made in' issue", 5-21.

${ }^{27}$ Noya, La imagen de España, 189-192.

${ }^{28}$ Noya, "La nueva etapa", 1-5.

${ }^{29}$ Kilduff and Núñez-Tabales, "Country image management”, 7-8.
} 
${ }^{30}$ Leca, "El branding made in Spain", 117.

${ }^{31}$ Royal Decree 998/2012.

32 Corbacho, Mínguez and Valderrama, "Percepción interna", 95- 97.

${ }^{33}$ Vangehuchten and Crespo, "Reinventar la Marca España", 9-10.

${ }^{34}$ Royal Decree 2010/1981.

35 Order of July 3, 1985.

36 “Generales 2015: ¿Qué ha hecho la política en moda en los últimos treinta años?” (Modaes.es, December 9, 2015).

37 Thomas, "Plan de promoción", 23-27.

${ }^{38}$ Quintas and Quintas, "La dimensión comunicativa", 208.

${ }^{39}$ Reply of the Government regarding the execution of the Global Fashion Plan (BOCG, Congreso de los Diputados, series D, nº. 313, February 27, 2002).

${ }^{40}$ Reply of the Government regarding the investment of the Institute of Foreign Trade to promote Spanish fashion (BOCG Congreso de los Diputados, series D, nº. 613, October 4, 2007).

${ }^{41}$ Replies of the Government regarding the Spanish Global Fashion Plan (BOCG, series D, nº 317 ,

March 6, 2002, and $8^{\text {th }}$ Term, series D, n'. 51, July 8, 2004).

42 ICEX Activity Reports, several years.

${ }^{43}$ Reply of the Government regarding the promotion of the fashion sector $\left(B O C G, 10^{\text {th }}\right.$ Term, D, $\mathrm{n}^{\circ} .446$, April 24, 2014, and $\mathrm{n}^{\circ}$ 505, July 30, 2014).

${ }^{44}$ Interbrand, Análisis del sector de la moda, 9.

45 Sojo, "Evolución y mejora," 40.

${ }^{46}$ LLonch, "Trademarks," 181-184.

${ }^{47}$ Catalan and Ramon-Muñoz, "Marshall in Iberia," 327-359.

${ }^{48}$ Sojo, "Evolución y mejora", 42-43.

${ }^{49}$ Bhardwaj and Fairhurst, "Fast fashion," 165-173.

${ }^{50}$ Inditex. Memoria anual 2015.

${ }^{51}$ Alonso, "Vistiendo a tres continentes", 160-162.

52 Crofton and Dopico, "Zara-Inditex," 45.

${ }^{53}$ Leca, "El branding Made in Spain", 11; Chislett, "The way forward for the Spanish Economy".

${ }^{54}$ Castellano, "El proceso de internacionalización," 212.

${ }^{55}$ Crofton y Dopico, "Zara-Inditex", 42.

56 Alonso, "Competitividad internacional”, 339-344; Martínez, "Hacia un nuevo sistema," 112-118.

${ }^{57}$ Annual reports of Mango.

58 Ibid.

${ }^{59}$ Rodríguez-Donaire, Casi and Carbonell. "Mango S.A.," 28.

60 "Mango cambia de estrategia para ser más competitiva" (Expansión, December 4, 2015) and Mango. Memoria de sostenibilidad 2015.

61 "Mango vuelve a bajar sus precios en el marco de su cambio de estrategia hacia el fast fashion"

(Moda.es, March 17, 2016).

${ }^{62}$ Salerno and Gay, El corazón de Mango.

${ }^{63}$ Caraballo, "Zara: Imagen de marca," 380-383.

\section{References}

Alonso, L. "Vistiendo a tres continentes: la ventaja competitiva del grupo Inditex-Zara, 1963-1999." Revista de Historia Industrial 18 (2000): 157-182.

Alonso, L. "Competitividad internacional e innovación tecnológica. El grupo Inditex 1985-2009." In Distritos y clusters en la Europa del sur, edited by J. Catalan, J. A. Miranda and R. Ramon-Muñoz, 337-350. Madrid: LID, 2011.

Belfanti, C. M. Civiltà della moda. Bologna: Il Mulino, 2008.

Belfanti, C. M. "History as an intangible asset for the Italian fashion business (19501954)." Journal of Historical Research in Marketing 7, no. 1 (2015): 74-90.

Belfanti, C. M. "Renaissance and 'Made in Italy': marketing Italian fashion through history (1949-1952).” Journal of Modern Italian Studies 20,1 (2015): 53-66. 
Belfanti, C. M. and E. Merlo. "Patenting fashion: Salvatore Ferragamo between craftmanship and industry", Investigaciones de Historia Económica - Economic History Research 12, 2 (2016): 109-119.

Bhardwaj, V. and A. Fairhurst. "Fast fashion: response to changes in the fashion industry." The International Review of Retail, Distribution and Consumer Research 20, no. 1 (2010): 165-173.

Capalbo, C. "Da sartorie a case di moda. L'evoluzione del comparto abbigliamento a Roma dall'Unità al secondo dopoguerra." Annali di storia dell'impresa 19 (2008): 191239.

Capalbo, C. "Creativity and innovation of the Italian fashion system in the inter-war period (1919-1943)." Investigaciones de Historia Económica - Economic History Research 12, 2 (2016): 190-99.

Caraballo, N. M. "Zara: Imagen de marca internacional y debut en la venta de moda online en Europa occidental." Intangible Capital 7, no. 2 (2011): 375-409.

Castellano, J. M. "El proceso de internacionalización de Inditex." Información Comercial Española 799 (2002): 209-217.

Catalan, J. and R. Ramon-Muñoz. "Marshall in Iberia. Industrial Districts and Leading Firms in the Creation of Competitive Advantage in Fashion Products." Enterprise \& Society 14, no. 2 (2013): 327-359.

Chislett, W. The Way Forward for the Spanish Economy: More Internationalisation. Working Paper 1/2010. Madrid: Elcano Royal Institute, 2010.

Colli, A. and E. Merlo. "Family business and luxury business in Italy (1950-2000)." Entreprises et Histoire 46, 1 (2007): 113-124.

Corbacho, J. M.; Míguez, M. I. and Valderrama, M. "Percepción interna y externa de la imagen de la marca España: análisis de métodos de evaluación." Sphera Publica (2014): 82- 99 .

Crofton, S. O and L. G. Dopico. "Zara-Inditex and the growth of fast fashion." Essays in Economic \& Business History 25 (2007): 41-54.

Cuervo-Cazurra, A. "Global Strategy and Global Business Environment: the Direct and Indirect Influences of the Home Country on a Firm's Global Strategy." Global Strategy Journal 1 (2011): 382-386.

Cuervo-Cazurra, A. and M. E. Genc. "Transforming disadvantages into advantages: developing country MNEs in the least developed countries." Journal of International Business Studies 39 (2008): 957-979.

Cuervo-Cazurra, A. and M. E. Genc. "Obligating, Pressuring, and Supporting Dimensions of the Environment and the Non-Market Advantages of Developing-Country Multinational Companies", Journal of Management Studies 48, no. 2 (2011): 441-455.

Donzé, P. Y. "From the Industrial District to the Global Firm: Swatch Group and the Swiss Watch Industry, 1960-2010.” Revista de Historia Industrial 66 (2017): 191-213.

Donzé, P. Y. "The transformation of global luxury brands:The case of the Swiss watch company Longines, 1880-2010.” Business History (forthcoming).

Donzé, P. Y. and R. Fujioka. "European luxury big business and emerging Asian markets, 1960 - 2010.” Business History 57, 6 (2015): 822-840. 
Font, L. M. "International couture: The opportunities and challenges of expansion, 18801920.” Business History 54, no. 1 (2012): 30-47.

Fontana, G. L. "Scarpe d'autore. Il calzaturiero della Riviera del Brenta dall'artigianato all' industria della moda (1950-1970)." Annali di storia dell'impresa 19 (2008): 241-264.

Hansen, H. "Networks, Narratives, and New Markets: The Rise and Decline of Danish Modern Furniture Design, 1930-1970." Business History Review 80, no. 3 (2006): 449483.

Interbrand. Análisis del sector de la moda española. Informe de resultados. Observatorio Industrial del Sector Textil y de la Confección: Madrid, 2009.

Jones, G. "Blonde and Blue-Eyed? Globalizing Beauty, c. 1945-c. 1980." Economic History Review, 61, no. 1 (2008): 125-154.

Jones, G. Beauty Imagined. A History of the Global Beauty Industry. Oxford University Press: New York, 2010.

Kilduff, K. and J. M. Núñez-Tabales. "Country image management: Brand Spain in the United States (U.S.).” Regional and Sectoral Economic Studies 14, no. 2 (2014): 5-16.

Leca, S. "El branding made in Spain. La marca España en la internacionalización de las marcas de calzado y moda.” PhD. diss., Universitat Ramon LLull, 2015.

LLonch, M. "Trademarks, product differentiation and competitiveness in the Catalan knitwear districts during the twentieth century." Business History 54, no. 2 (2012): 179200 .

Martínez, A. "Hacia un nuevo sistema de la moda. El modelo Zara." Revista Internacional de Sociología 66, no. 51 (2008): 105-122.

Merlo, E. "Le origini del sistema moda." In Storia d'Italia. Annali 19. La moda, edited by C. M. Belfanti and F. Giusberti, 667-697. Torino: Giulio Einaudi, 2003.

Merlo, E. "Italian fashion business: Achievements and challenges (1970s-2000s)." Business History 53, no. 3 (2011): 344-362.

Merlo, E. and F. Polese. "Turning Fashion into Business: The Emergence of Milan as an International Fashion Hub.” Business History Review 80, no. 3 (2006): 415-447.

Merlo, E. and F. Polese. "Costruire una capital della moda. Milano: le premesse ottocentesche, il risveglio degli anni Cinquanta." Annali di storia dell'impresa 19 (2008): 49-108.

Meyer, K. E., R. Mudambi and R. Narula. "Multinational Enterprises and Local Contexts: The Opportunities and Challenges of Multiple Embeddedness." Journal of Management Studies 48 (2011): 235-252.

Moon, B. J. "Effects of Consumer Ethnocentrism and Product Knowledge on Consumers' Utilization of Country-of-Origin Information." Advances in Consumer Research 31 (2004): 667-673.

Morello, G. "The 'made in' issue: a comparative research on the images of domestic and foreign products." European Research 12, no. 1 (1984): 5-21.

Noya, J. La imagen de España en el exterior. Estado de la cuestión. Madrid: Real Instituto Elcano, 2002.

Noya, J. “La nueva etapa de la marca España”. Boletín Elcano 37 (2004): 1-5. 
Paris, I. "Orígenes del Made in Italy: Moda italiana y mercado internacional en la segunda posguerra (1951-1969)." Revista de Historia Industrial 42 (2010): 121- 154.

Pinchera, V. "Firenze e la nascita della moda italiana: dai drappi alla Sala Bianca." Annali di storia dell'impresa 19 (2008): 133-190.

Pouillard, V. "Design Piracy in the Fashion Industries of Paris and New York in the Interwar Years," Business History Review 85, no. 2 (2011): 319-344.

Pouillard, V. "Managing fashion creativity. The history of the Chambre Syndicale de la Couture Parisienne during the interwar perior." Investigaciones de Historia EconómicaEconomic History Research 12, 2 (2016): 76-89.

Quintas, N. and Quintas, E. "La dimensión comunicativa de la moda: apuntes del caso español”, Zer, 15, 28 (2010): 197-212.

Real Instituto Elcano. Barómetro de la imagen de España (BIE). 5 a oleada. Resultados de diciembre 2014-enero 2015. Madrid: Real Instituto Elcano, 2015.

Rezvani, S., G. J. Dehkordi, M. S. Rahman, F. Fouladivanda, M. Habibi, and S. Eghtebasi. "A conceptual study on the country of origin effect on consumer purchase intention." Asian Social Science, 8, no. 12 (2012): 205-215.

Riello, G. "La chaussure à la mode: Product Innovation and Marketing Strategies in Parisian and London Boot and Shoemaking in the Early Nineteenth Century", Textile History 34, 2 (2003): 107-133.

Rodríguez-Donaire, S.; Casi, E. and Carbonell, X. "Mango S.A.: reinventando el sector de la moda." Universia Business Review 23 (2009): 26-39.

Roth, M. S. and J. B. Romeo. "Matching Product Category and Country Image Perceptions: A Framework for Managing Country-Of-Origin Effects." Journal of International Business Studies 23, no. 3 (1992): 477-497.

Salerno, H. and A. Gay. El corazón de Mango. Madrid: LID, 2010.

Sojo, F. J. "Evolución y mejora en la competitividad de las empresas del sector textilconfección." Economía industrial 385 (2012): 39-46.

Thomas, C. "Plan de promoción para el diseño, la calidad y la moda." Política Científica 25 (1990): 23-27.

Umemura, M. "Reaching for global in the Japanese cosmetics industry, 1951 to 2015: the case of Shiseido." Business History (forthcoming).

Usunier, J. C. "Relevance in business research: the case of country-of-origin research in marketing”. European Management Review, 3 (2006): 60-73.

Vangehuchten, L. and M. Crespo. "Reinventar la Marca España en tiempos de crisis: un análisis comunicativo de la campaña española de nation branding." Ámbitos. Revista internacional de comunicación 24 (2014): 1-15.

Vrontis, D., A. Thrassou, and C. Vignali. "The country-of-origin effect on the purchase intention of apparel: opportunities and threats for small firms." International Journal of Entrepreneurship and Small Business 3, no. 3-4 (2006): 459-476.

Wall, M. and L. A. Heslop. "Consumer attitudes towards the quality of domestic and imported apparel and footwear." Journal of Consumer Studies \& Home Economics 13, no. 4 (1989): 337-358. 
Wang, C. L., D. Li, B. R. Barnes, and J. Ahn. "Country image, product image and consumer purchase intention: Evidence from an emerging economy." International Business Review 21 (2012): 1041-1051.

White, N. Reconstructing Italian Fashion. America and the Development of the Italian Fashion Industry. Oxford: Berg, 2000. 